\title{
The use of Infrared Thermography and Thermo-Aeraulic Simulation to Approach the Real Performance of Existing Buildings
}

\author{
Hajar Benhmidou ${ }^{1}$, Zaid Romani ${ }^{2}$, Mohamed El Mankibi ${ }^{3}$, Abdeslam Draoui ${ }^{1}$ \\ ${ }^{1}$ Team of Heat Transfer \& Energetic, FST of Tangier, Abdelmalek Essaâdi University, \\ Tangier, Morocco. \\ ${ }^{2}$ National School of Architecture Tetouan, Tetouan, Morocco. \\ ${ }^{3}$ LGCB, ENTPE, Vaulx-en-Velin, France.
}

\begin{abstract}
The objective of this study is to develop a relatively simple accurate method to represent the current energy state of an existing building to ensure its optimal rehabilitation. Firstly, infrared thermography was used to estimate the envelope thermal transmission coefficient (U). Secondly, the dynamic building simulations were realized through TRNSYS 17 to determine the studied building's energy performances. Each element of the envelope receives a measured $U$ to represent the as is building condition. Finally, in this study, we have coupled CONTAM software with TRNSYS to evaluate the thermo-aeraulic behaviour of an existing building located in the north of Morocco.
\end{abstract}

\section{Introduction}

The building sector accounts for $34.96 \%$ of the primary energy use in Morocco which is greater than the industrial sector (Energy Efficiency 2018). 26.37\% and 8.32\% of this energy use is consumed by residential and tertiary buildings respectively, where a vast majority is still produced using non-renewable resources. Following dynamics development of Morocco in this sector (Lahlou 2011), this energy demand will increase in the future, hence it is essential to reduce buildings energy loads in particularly by improving energy efficiency of existing buildings. A key challenge of reducing the energy use in existing building is to characterize and provide accurate representation of the as-is energy building conditions (Larsen et al. 2011). As without accurate representation of the as-is building conditions, it is difficult to choose from a range of high cost solutions and services and then achieve an optimal renovation of the studied buildings.

Over the past 30 years, literally many of building energy programs (TRNSYS, EnergyPlus, EQUEST, DOE-2, ESP-r, ECOTECT, DeST, Energy-10, PowerDomus, HEED, Ener-Win, SUNREL and Energy Express) have been developed to predict the existing building's energy performance. In this context, several studies have been carried out on the prediction of the existing building's energy performance using some of this building energy software (Ferrante, Mihalakakou, and Odolini 1997; Florides et al. 2002; Babbah et al. 2005; Al-ajmi and Hanby 2008; Saelens, Parys, and Baetens 2011; Gasparella et al. 2011; Domínguez et al. 2012; Friess et al. 2012; Beccali et al. 2013; Gagliano et al. 2013; Romani et al. 2015; Cascio et al. 2017; Lebied et al. 2018).

Despite the effectiveness of these energy modelling, they present some limits:

- Non-determination of the performance deviations caused by construction defects or degradations;

- Non-representation of the actual energy performances, since the as-is building envelope during the modelling process is not taken into account.

To address this situation, in this paper, we propose to use infrared thermography (IRT) to integrate real building characteristic, through a case study involving a host building located in Tangier (north of Morocco). Today, the IRT is widely used to detect, to analyse thermal defects and to evaluate the buildings thermal performances. In this respect, several studies have been demonstrating the IRT potential in the estimation of the existing buildings actual thermal performance (Balaras and Argiriou 2002; Kato, Kuroki, and Hagihara 2007; Kalamees 2007; Albatici and Tonelli 2010; Fokaides and Kalogirou 2011; Asdrubali, Baldinelli, and Bianchi 2012; Dall'O', Sarto, and Panza 2013; Kylili et al. 2014; Ohlsson and Olofsson 2014; Danielski and FrOling 2015; Tejedor et al. 2017; Rocha and Santos, C F Póvoasb $2018 b ; 2018 a$ ).

In order to identify the building Envelope's heat lose, an experimental protocol was carried out. Thereafter, the different outside surface temperatures of the building envelope are used to estimate the in-situ thermal transmission coefficient (U-value). The obtained Uvalues were then used for the energy modelling of the studied building using TRNSYS 17 software, where each envelope element receives a U-value measured during the diagnosis. Finally, this building real energy needs were estimated through coupling of the TRNSYS energy simulation program with the CONTAM multizone airflow to choose the appropriate solutions for an optimum renovation of the studied building (Figure 1). 


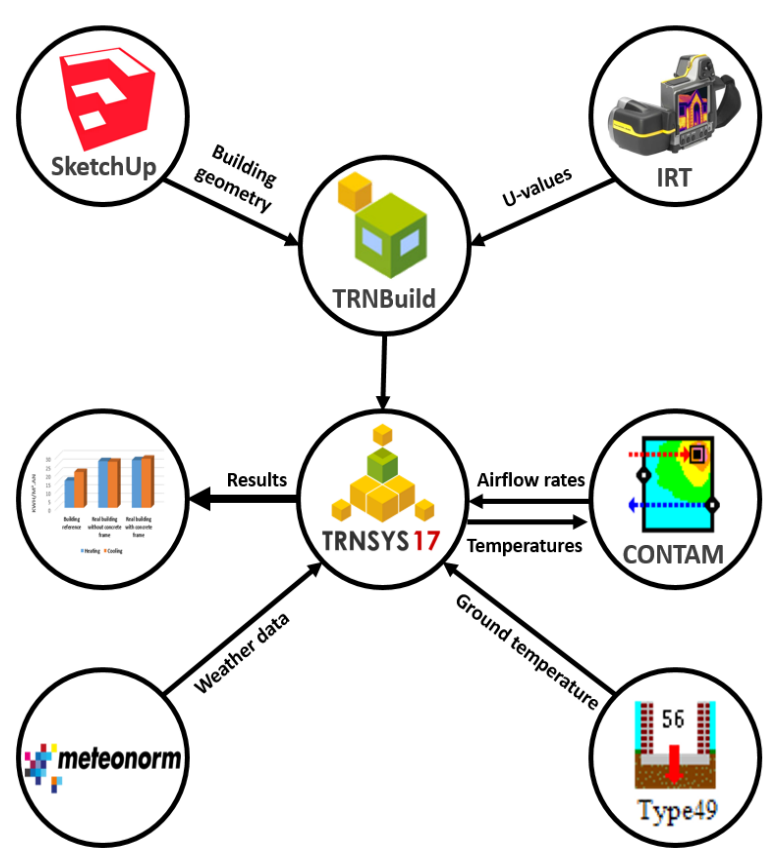

Figure 1: Schematic description of the studied approach to estimate the buildings real energy performances.

\section{Methodology}

\section{Building description}

The assessed building is one of the two host buildings located in north of Morocco. It consists of a ground floor and a first floor (Figure 2), giving a space living area of $44.39 \mathrm{~m}^{2}$ with a ceiling height of $2.8 \mathrm{~m}$. This building is equipped with single glazed wooden windows which are distributed on the South and North outside walls. The overall window rate is $5.87 \%$.

(a)

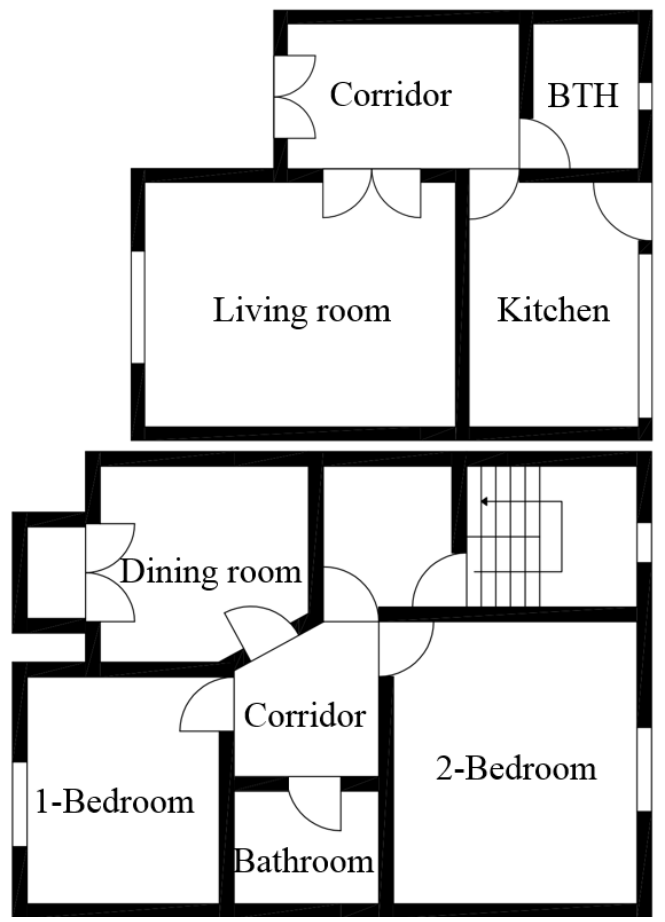

(b)

Figure 2 : Plan of the studied building ground floor (a) and first floor $(b)$.
In order to have the composition of the building's walls we have drilled a small hole (Figure 3) in the wall as shown in the figure below.
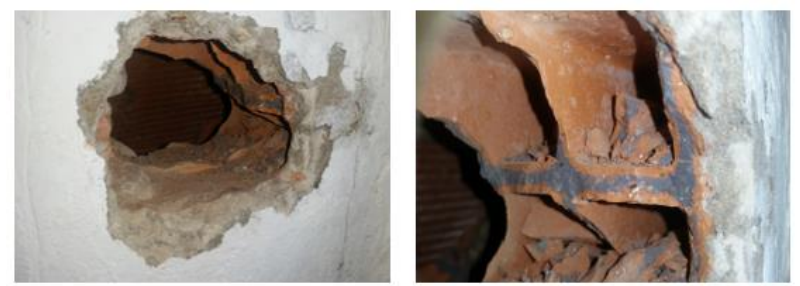

Figure 3 : The small hole on the outside wall.

The thermal conductivity of some building materials such as brick is measured using the hot box method of the Thermal, Solar Energy and Environment team from the Faculty of Sciences in Tetouan. The air gap thermal conductivity is obtained according to the thickness of this layer("The Thermal Resistance of the Air Layers" n.d.). Table 1 summarizes the composition of building outside wall, ceiling and roof.

Table 1 : The outside walls and the floors structure.

\begin{tabular}{|c|c|c|c|c|}
\hline $\begin{array}{l}\text { Walls } \\
\text { and } \\
\text { floors }\end{array}$ & $\begin{array}{c}\text { Materials } \\
\text { (layers) }\end{array}$ & $\begin{array}{c}\text { Thickness } \\
{[\mathrm{cm}]}\end{array}$ & $\begin{array}{c}\text { Conductivity } \\
{[\mathbf{W} /(\mathbf{m} . \mathbf{K})]}\end{array}$ & $\begin{array}{c}\mathrm{U}- \\
\text { total } \\
\text { value } \\
{[\mathrm{W} / \mathrm{m}} \\
2 \mathrm{~K}]\end{array}$ \\
\hline \multirow{6}{*}{$\begin{array}{l}\text { Outside } \\
\text { wall }\end{array}$} & $\begin{array}{l}\text { Cement } \\
\text { coating }\end{array}$ & 1.5 & 1.15 & \multirow{5}{*}{1.88} \\
\hline & $\begin{array}{l}\text { Hollow } \\
\text { brick red }\end{array}$ & 7 & 0.5 & \\
\hline & Air gap & 10 & - & \\
\hline & $\begin{array}{l}\text { Hollow } \\
\text { brickred }\end{array}$ & 7 & 0.5 & \\
\hline & $\begin{array}{l}\text { Cement } \\
\text { coating }\end{array}$ & 1.5 & 1.15 & \\
\hline & $\begin{array}{c}\text { Tiles } \\
\text { (kitchen } \\
\text { wall) }\end{array}$ & 0.7 & 1.4 & 1.86 \\
\hline \multirow{6}{*}{ Roof } & $\begin{array}{l}\text { Cement } \\
\text { coating }\end{array}$ & 0.4 & 0.42 & \multirow{6}{*}{2.77} \\
\hline & $\begin{array}{l}\text { Waterpro } \\
\text { ofing } \\
\text { membran } \\
\text { e } \\
\end{array}$ & 0.7 & 0.23 & \\
\hline & $\begin{array}{c}\text { Cement } \\
\text { mortar }\end{array}$ & 1 & 0.42 & \\
\hline & Concrete & 4 & 2.3 & \\
\hline & $\begin{array}{c}\text { hollow } \\
\text { block }\end{array}$ & 16 & 0.6 & \\
\hline & $\begin{array}{l}\text { Cement } \\
\text { coating }\end{array}$ & 1.5 & 1.15 & \\
\hline \multirow{5}{*}{ Ceiling } & Tiles & 0.7 & 1.4 & \multirow{5}{*}{3.06} \\
\hline & $\begin{array}{c}\text { Cement } \\
\text { mortar }\end{array}$ & 1 & 0.42 & \\
\hline & Concrete & 4 & 2.3 & \\
\hline & $\begin{array}{c}\text { hollow } \\
\text { block }\end{array}$ & 16 & 0.6 & \\
\hline & $\begin{array}{l}\text { Cement } \\
\text { coating }\end{array}$ & 1.5 & 1.15 & \\
\hline
\end{tabular}




\section{Building thermal diagnostics}

As already mentioned above, the infrared thermography was used to carry out a thermal diagnosis in order to represent with accuracy the actual thermal state of the studied building. In this thermal diagnosis, the used infrared thermal camera (Figure 4) was a model type Flir E50bx (2012) with an operating temperature range between $-20^{\circ} \mathrm{C}$ and $+120^{\circ} \mathrm{C}$ and a precision of $\pm 2{ }^{\circ} \mathrm{C}$ or $\pm 2 \%$ of the displayed value. Furthermore, temperature loggers type Tinytag ULTRA2 (Figure 4) have been used to measure temperature with an accuracy of $\pm 0.4^{\circ} \mathrm{C}$ and relative humidity between 0 and $95 \%$ with an accuracy of $\pm 3.0 \%$ RH (Ultra, 2014).

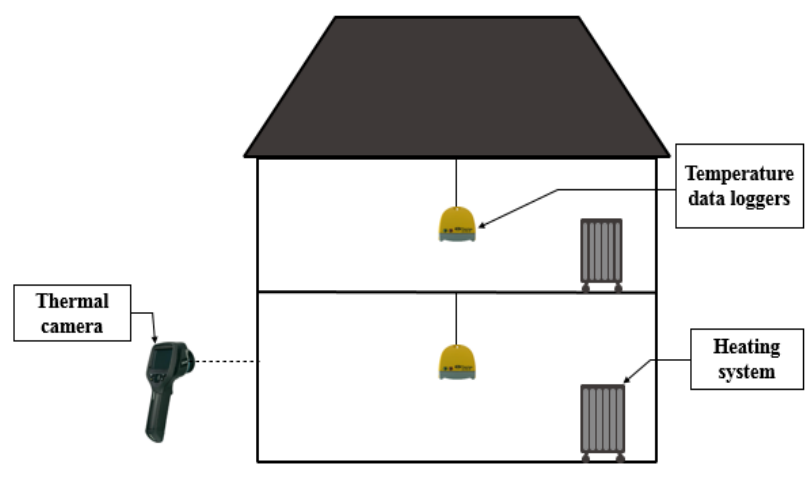

Figure 4 : Schematic drawing of the experimental protocol.

Before making the measurements, the thermal camera should be calibrated for the studied element to avoid readings errors on the obtained thermal imagery. In other words, the reflected ambient temperature $\left(T_{\text {reflected }}\right)$ and the emissivity $(\varepsilon)$ of the studied building envelope are required to be measured. In this study, the reflective temperature was measured by means of a crumpled aluminium foil fixed on the surface (Figure 5) where the emissivity of the thermal camera at this measuring point was set at 1 . This process is performed at each thermal image capture.

The determination of the emissivity value $(\varepsilon)$ can be achieved by two methods, the first one is based on the reference emissivity values according to the type of material and the second one is through the direct measurement of the radiation reflected by the material by means of a heat source. In this study, the measurement of the wall's emissivity is performed according to the in situ method because it depends not only on the surface materials, but on the real surface conditions suffering from pollution, humidity, roughness and so on. We first moving a hot elements close to the wall surface as a soldering iron (Figure 6) and through applying the Energy Conservation Law (between an energy source and an opaque element) and Kirchhoff's Law, the thermal emissivity can be expressed as follows:

$$
\varepsilon=1-\left[\frac{T_{r}^{4}-T_{\text {out }}^{4}}{T_{s}^{4}-T_{\text {out }}^{4}}\right]
$$

Where $T_{s}$ is the hot source temperature, $T_{r}$ is the reflected image temperature and $T_{\text {out }}$ is the outside air temperature.

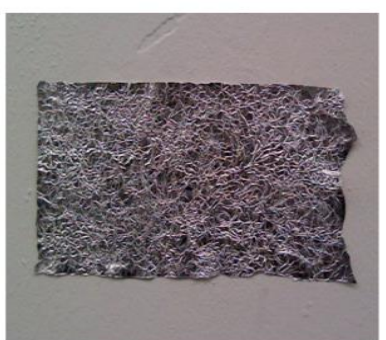

(a)

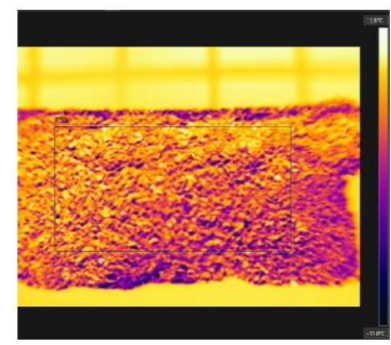

(b)
Figure 5: Arrangement for determination of reflected temperature: digital image (a) and thermogram (b).

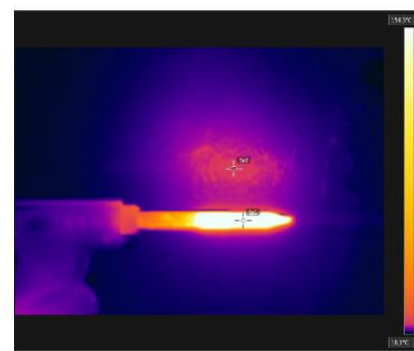

Figure 6: Thermal image of the soldering iron used to measure emissivity.

Therefore, the envelope temperature distributions can be obtained by the thermal imagery adjusted with the found emissivity value. Finally, the building envelope thermal transmission coefficient $U(2)$ can be estimated based on the obtained envelope temperatures by assuming that the heat transfer from the envelope to the camera is mainly attributed to heat flow by convection $\left(\boldsymbol{\Phi}_{c v}\right)$ and heat flow by radiation $\left(\boldsymbol{\Phi}_{\text {rad }}\right)$, given by equations (3) and (4) (Fokaides and Kalogirou 2011)(Nardi et al. 2016).

$$
\begin{gathered}
U=\frac{\Phi_{c v}+\Phi_{\text {rad }}}{S\left(T_{\text {in }}-T_{\text {out }}\right)} \\
\Phi_{c v}=h_{c v, \text { out }} \times S \times\left(T_{\text {wall }, \text { out }}-T_{\text {out }}\right) \\
\Phi_{\text {rad }}=\varepsilon \times \sigma \times s \times\left(T_{\text {wall }, \text { out }}{ }^{4}-T_{\text {reflected }}{ }^{4}\right)
\end{gathered}
$$

Here $h_{c v, \text { out }}$ is the outside convective heat transfer coefficient $\left(\mathrm{W} / \mathrm{m}^{2} . \mathrm{K}\right), T_{\text {wall,out }}$ is the wall temperature, $\mathrm{T}_{\text {reflected }}$ is the reflected temperature, $\mathrm{T}_{\text {out }}$ is the outdoor air temperature, all expressed in Kelvin, $\varepsilon$ is the wall emissivity and $\sigma$ is the Stephan-Boltzmann constant. The convective heat transfer coefficient $h_{c v, \text { out }}$ is calculated using Liu and Harris correlations (2015) as presented in Table 2 .

Table 2 : Expressions used in the model by Liu \& Harris for $V_{l o c}$ and $V_{R}$ as function of $V_{I 0}$.

\begin{tabular}{|c|c|c|}
\hline \multirow{2}{*}{$\begin{array}{c}\text { Surface } \\
\text { orientation }\end{array}$} & \multicolumn{2}{|c|}{ Expression } \\
\cline { 2 - 3 } Windward & $\mathrm{V}_{10}$ and $\mathrm{V}_{\text {loc }}=0.26 \mathrm{~V}_{10}+0.06$ & $\mathrm{~V}_{\mathrm{R}}=0.55 \mathrm{~V}_{10}+0.67$ \\
\hline Leeward & $\mathrm{V}_{\mathrm{loc}}=0.19 \mathrm{~V}_{10}+0.14$ & $\mathrm{~V}_{\mathrm{R}}=0.43 \mathrm{~V}_{10}+0.24$ \\
\hline
\end{tabular}

Where $V_{l o c}$ is the wind speed measured at a certain distance $\mathrm{d}$ from the building facade and at a certain height $(H)$ from the ground, $V_{l 0}$ is the wind speed measured at $10 \mathrm{~m}$ above ground level in the upstream undisturbed wind flow and $V_{R}$ is the wind speed measured at height $H_{0}$ from the roof surface. 
A heating system was installed within the building 15 days (360 hours) before the diagnosis to achieve steadystate regime. Figure 7 shows the evolution of the inner air temperature during the thermal diagnosis process.

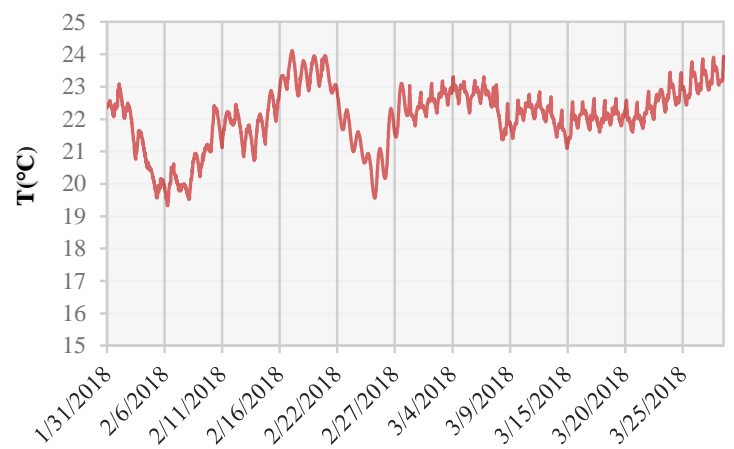

Figure 7: Inside air temperature profile measured by Tinytag data loggers.

Therefore, a temperature difference of more than $10^{\circ} \mathrm{C}$ was ensured between the building inside and outside with an outside air velocity of about $2.05 \mathrm{~m} / \mathrm{s}$. Given that the outside temperature is measured by the Ibn Battouta airport weather station in Tangier, due to the proximity of the airport to the studied building. In fact, we have performed the diagnosis several times during the winter season as February twenty-three, February twenty-eight and March twenty-three (Figure 8), before sunrise to avoid the solar radiation influence.

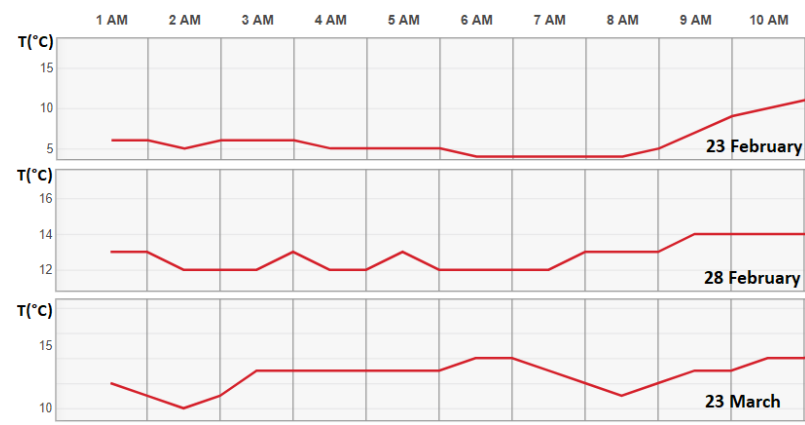

Figure 8: Outside air temperature profile.

The building Envelope's heat lose (Figure 9), were visualized then using the infrared camera in the facades and the roof. All the $U$-values measured with IRT were used subsequently in the studied building energy modelling.

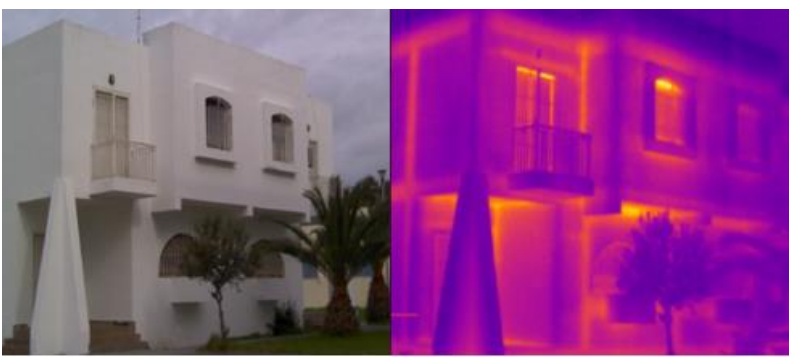

Figure 9: Digital and thermal image of the studied building.

Before proceeding to the temperatures reading through the FLIR Tools software we compared the obtained temperature values with a thermocouple measurement. the results of this comparative study showed a good agreement between the values measured by the thermography and the thermocouple values. Moreover, to calculate the U-values from the obtained thermal imagery, we have carried out a zoning on the building envelope, for both the walls (A) and the concrete framework (B) in the obtained image (Figure 10).
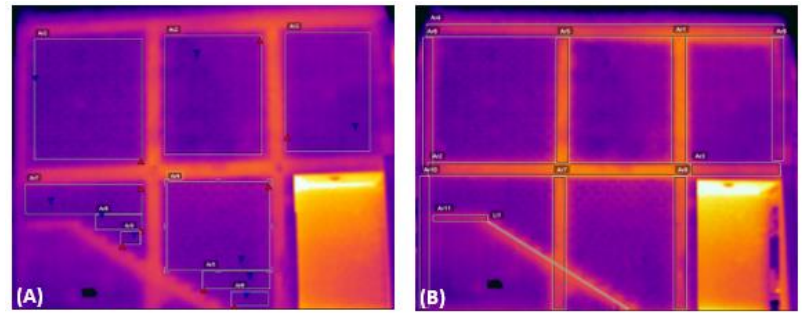

Figure 10: The zoning carried out in the lateral facade.

We have also performed this zoning process for all building envelope surfaces (Figure 11) to obtain the different temperature values of the studied building envelope surfaces and then calculate the in-situ thermal transmission coefficient.

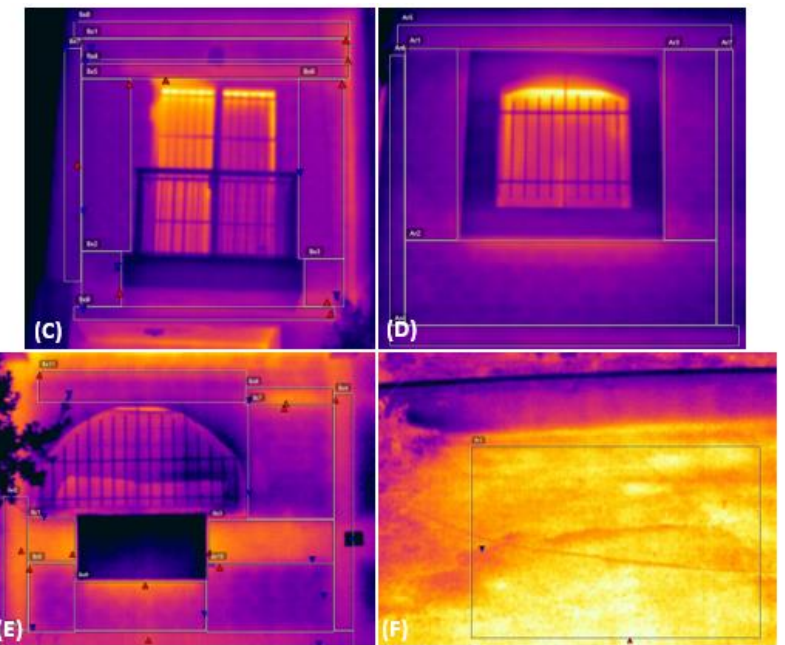

Figure 11: Thermal images of the studied building envelope areas.

As an example, table 3 groups the average value $U$ of all in situ test results for the case of image $\mathrm{C}$ in the figure 11.

Table 3 : $U$-value measured with IRT for image $C$.

\begin{tabular}{|c|c|c|c|c|c|c|}
\hline $\begin{array}{c}\text { envel } \\
\text { ope } \\
\text { part }\end{array}$ & wall & $\begin{array}{c}\text { Left } \\
\text { post }\end{array}$ & $\begin{array}{c}\text { Right } \\
\text { post }\end{array}$ & $\begin{array}{c}\text { high } \\
\text { beam }\end{array}$ & $\begin{array}{c}\text { Low } \\
\text { beam }\end{array}$ & Roof \\
\hline $\begin{array}{c}\mathrm{U}_{\text {meas }} \\
{[\mathrm{W} / \mathrm{m}} \\
2\end{array}$ & $\begin{array}{c}2.8 \\
\pm 0.7\end{array}$ & $\begin{array}{c}2.35 \\
\pm 0.6\end{array}$ & $\begin{array}{c}2.36 \\
\pm 0.5\end{array}$ & $\begin{array}{c}4.54 \\
\pm 0.69\end{array}$ & $\begin{array}{c}4.40 \\
\pm 0.62\end{array}$ & $\begin{array}{c}5.41 \\
\pm 0.7\end{array}$ \\
\hline $\begin{array}{c}\mathrm{U}_{\mathrm{th}} \\
{[\mathrm{W} / \mathrm{m}}\end{array}$ & 1.88 & 1.41 & 1.41 & 1.64 & 1.32 & 2.77 \\
$\left.{ }^{2} \mathrm{~K}\right]$
\end{tabular}

As it can be seen, that the building element which gives the greater deviation in all cases tested is the roof, followed by the concrete frame structure. At the facade level, according to this study the maximum values of the $\mathrm{U}$-value are obtained in the areas located on the first floor 
and the most possible explanation is the proximity of this area to the ground and the accumulation of hot air in the corners. It is highly possible that part of the difference between the measured results and those calculated analytically to be due to the fact that the theoretical calculation of the U-value deviates from the real condition due to the degradation of the building envelope during the construction and operation phases. All these U-values were used subsequently in the studied building energy modelling as explained below.

\section{Building modeling}

After the realization of the thermal diagnosis and the estimation of the building envelope surfaces real Uvalues, we have proceeded to the thermo-aeraulic modelling of this building. We have performed a comparison study of three different cases of our building: the reference building by using the theoretical U-values, the building diagnosed by using measured U-values for walls without the concrete framework (Figure 12) and the building diagnosed with the concrete framework (Figure 13) by using both measured U-values.

In this part, the building geometry, its operation and the thermo-aeraulic numerical model are developed under the TRNSYS-CONTAM environment. The building geometry was obtained by using Google Sketchup software and then saved with TRNSYS 3d plug-in (Figure 12 and 13). In fact, we have divided the building into different zones and we have considered that each room is a thermal zone.

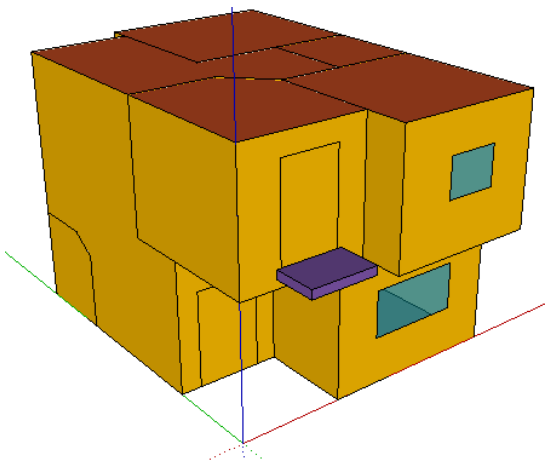

Figure 12 : TRNSYS3d representation of studied building without the concrete framework.

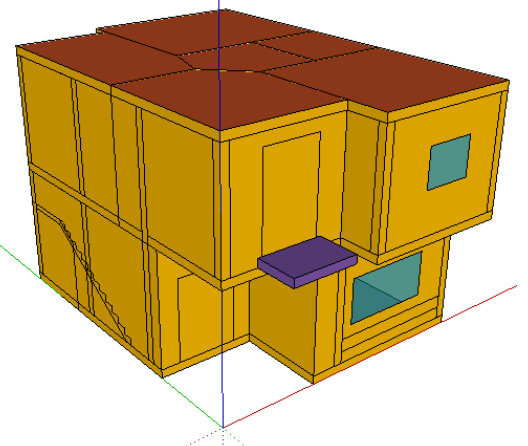

Figure 13 : TRNSYS3d representation of studied building with the concrete framework.
In this modelling, it is essential to take into account the different contributions of heat gains from different sources: people, lighting and equipment. In this context, we supposed that our building is occupied by four people. Each room in the building has a gain that depends on the activity level of these people and their occupation. Concerning the person's activity level, it has been considered in accordance with the ISO 7730.

Regarding the occupation, the two bedrooms are occupied every day from $22 \mathrm{~h}$ to $7 \mathrm{~h}$. The living room is used for relaxing in the evening, so it is occupied from $17 \mathrm{~h}$ to $18 \mathrm{~h}$ by four people. However, the dining room is used only for eating meals (breakfast, lunch and dinner). The kitchen is occupied by two people during the day from $7 \mathrm{~h}$ to $7 \mathrm{~h} 30$, $12 \mathrm{~h} 30$ to $12 \mathrm{~h}$ and from $18 \mathrm{~h}$ to $19 \mathrm{~h}$.

The contributions due to the artificial lighting depend on the type of lamp used, as well as the installed power and the operating period. We have opted for our study on incandescent lamps of $100 \mathrm{~W}$ (the same lamps used in the building studied) for an operating period from $19 \mathrm{~h}$ to $23 \mathrm{~h}$. The building is equipped with different types of equipment that are shown in the table4.

Table 4: Power generated by the appliances.

\begin{tabular}{|c|c|c|c|}
\hline Appliance & Area & Operating time & $\begin{array}{c}\text { Power } \\
\text { [W] }\end{array}$ \\
\hline TV & Living room & $\begin{array}{c}\text { In occupation } \\
\text { from 17h to 18h }\end{array}$ & 75 \\
\hline Laptop & 2-bedroom & $\begin{array}{c}\text { In occupation } \\
\text { from 22h to 23h }\end{array}$ & 100 \\
\hline Fridge & kitchen & 24/24 & 125 \\
\hline
\end{tabular}

Moreover, the ground three dimensional modelling is performed to account the thermal effect of the ground in the energy balance of the studied building by using the coupling between the 56 types (thermal model of the building) and 49 (slab on grade model). In this regard, we considered a distance of $10 \mathrm{~m}$ from the slab in each direction $(x, y$ and $z$ ). The temperature in the horizontal plane at $10 \mathrm{~m}$ depth is calculated by the model of Kusuda (Kasuda; and Achenboch 1965) given by equation (5) while the vertical boundaries are supposed adiabatic.

$T_{s z}(t)=T_{s u, m o y}+\Delta T_{s u} \cdot e^{-z \sqrt{\frac{\pi}{a_{s o l} \cdot \Delta t}}} \cos \left(\frac{2 \pi t}{\Delta t}-z \cdot \sqrt{\frac{\pi}{a_{s o l} \cdot \Delta t}}\right)$

With $\Delta T_{s u}$ is the amplitude of surface temperature variation over the considered period, $\Delta t$ is the considered period and $a_{\text {sol }}$ is the thermal diffusivity of the ground.

On the other hand, we have chosen to perform a coupling between the thermal model developed under TRNSYS and an aeraulic model via CONTAM software in order to simulate thermal and energy parameters as well as the air flows between the studied zones and between the zones and the outdoors, knowing that the airtightness of this building is equal to $0.621 \mathrm{~h}^{-1}$. The advantage of this coupling is that the temperatures in the building areas depend on the air flows, which in turn depend on the temperature differences. However, the TRNSYS software does not calculate the airflows between the building zones 
and the airflow programs such as the CONTAM software do not model the building's thermal energy.

As for the thermal model, the studied building is divided into different zones (rooms or groups of rooms), connected by openings (doors, windows, cracks or leaks, ventilation ducts or air openings) (Barhoun 2006). The studied building model under CONTAM is a multi-zone nodal model. Although the CONTAM does not require the plans full-scale drawing for airflow calculations, the graphical interface allows a scaling value to be assigned for the drawing cells. This option was used in the studied building plan for later used with Google Sketchup and TRNSYS. Air flows through the building (Figure 14) result from pressure differences between adjacent areas or between an inside area and the outside of the building. These pressure differences are governed by the natural ventilation motors which are wind effect and thermal draught. The various flow rates are calculated by expressing the mass conservation equation at each of the network nodes. The air temperature is known by coupling with the type56 which receives as input the flow rates calculated by CONTAM (type97).

口ambt

(a)

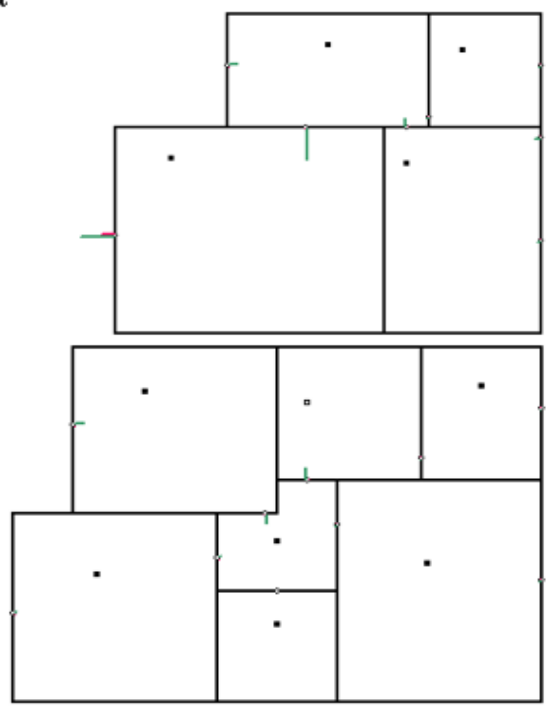

Figure 14: Airflow and pressure distributions in the ground floor $(a)$ and the first floor $(b)$ calculated by CONTAM.

During this modelling, the space cooling and space heating demands are determined considering the room air temperatures controlled to remain at $20^{\circ} \mathrm{C}$ during the winter (the statutory heating period in Tangier from $1 \mathrm{st}$ November to 15 th April) and $26^{\circ} \mathrm{C}$ during summer (considering as cooling period the days in which the internal temperature exceeds $26^{\circ} \mathrm{C}$ ). The value of external convective heat transfer coefficient for building envelope is assumed to be constant and equal to $17.8 \mathrm{~W} / \mathrm{m}^{2} \mathrm{~K}$ and for the internal side, the value chosen is $3 \mathrm{~W} / \mathrm{m}^{2} \mathrm{~K}$ (Klein et al. 2010).

\section{Results and discussion}

To evaluate the energy performance of the studied building, we carried out a comparative study between the obtained results from numerical simulations for the three cases (Figure 15): the reference building (a), the building diagnosed without the concrete framework (b) and the building diagnosed with the concrete framework (c).
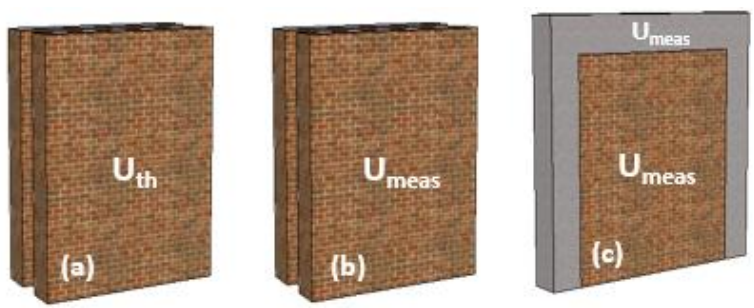

Figure 15: The three studied approaches.

As shown in the figure below, the building diagnosed with the concrete framework has about $75.4 \%$ higher heating needs than the building reference and $2.12 \%$ higher than the diagnostic building without the framework.

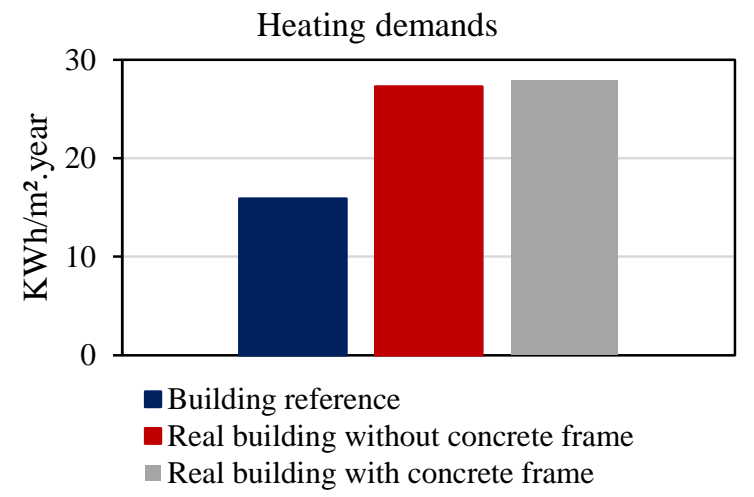

Figure 16: Building heating demand.

On the other hand, the building diagnosed with the concrete framework cooling needs are $48.05 \%$ higher than those of the building reference and $7.16 \%$ higher than those of the diagnostic building without the framework (Figure 17).

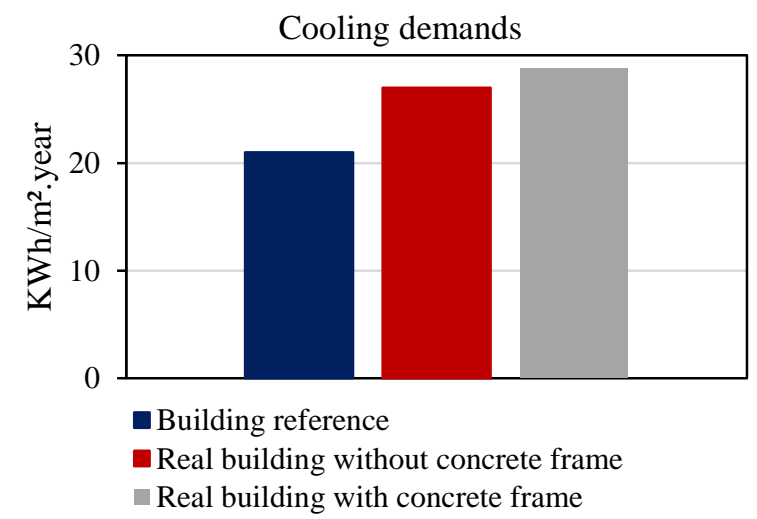

Figure 17: Building cooling demand.

This comparative study between the obtained results for the building reference and the diagnosed building with and without concrete framework shows the importance of the existing buildings energy diagnosis to increase the buildings energy efficiency and their indoor comfort. Indeed, the energy diagnosis allows us to represent the 
real energy state of buildings using the estimated thermal transmittance U.

\section{Conclusion}

This research work concerns an energetic performance study of a building located in Tangier (north of Morocco) to ensure its optimal rehabilitation. Firstly, a nondestructive measurement using infrared thermography was performed to detect, analyse the thermal defects and evaluate this building thermal performances. An experimental protocol was carried out to identify the building Envelope's heat lose and then the different outside surface temperatures of the building envelope are used to estimate the in-situ thermal transmission coefficient (U-value). Those measurements were repeated several times, during the winter season, before with at least $10-15^{\circ} \mathrm{C}$ difference between inside and outside temperature to allow a measurable heat exchange through the envelope. The obtained U-values were then used for the Thermo-aeraulic modelling which is essential for establishing the studied building energy performance under different interior and exterior climate conditions. The building geometry it's developed under the TRNSYS17-CONTAM environment and then each envelope element receives a U-value measured during the diagnosis. Afterwards, the energy simulation is performed for three cases: the reference building, the building diagnosed without the concrete framework and the building diagnosed with the concrete framework in order to determine the accurate studied building's energy performances and heating/cooling energy needs. Finally, after having estimated the real energy needs of the studied building we will proceed to an optimization study to choose the appropriate solutions for an optimal rehabilitation of the studied building.

\section{References}

Al-ajmi, Farraj F, and V I Hanby. 2008. "Simulation of Energy Consumption for Kuwaiti Domestic Buildings" 40: 1101-9. https://doi.org/10.1016/j.enbuild.2007.10.010.

Albatici, Rossano, and Arnaldo M. Tonelli. 2010. "Infrared Thermovision Technique for the Assessment of Thermal Transmittance Value of Opaque Building Elements on Site." Energy and Buildings $\quad 42 \quad$ (11): 2177-83. https://doi.org/10.1016/j.enbuild.2010.07.010.

Asdrubali, Francesco, Giorgio Baldinelli, and Francesco Bianchi. 2012. "A Quantitative Methodology to Evaluate Thermal Bridges in Buildings." Applied Energy 97: 365-73. https://doi.org/10.1016/j.apenergy.2011.12.054.

Babbah, S, A Draoui, C H Menezo, R Yezou, and J B E N Abdelouahab. 2005. "Evaluation Energétique Des Bâtiments Au Nord Du Maroc." In 12èmes Journées Internationales de Thermique, 235-38.

Balaras, C. A., and A. A. Argiriou. 2002. "Infrared Thermography for Building Diagnostics." Energy and Buildings $34 \quad$ (2): 171-83. https://doi.org/10.1016/S0378-7788(01)00105-0.

Barhoun, Hayssam. 2006. "Influence Des Transferts Aérauliques Dans Les Parois Sur Leurs Performances Thermiques," 251. https://doi.org/Doi 10.1016/S0022-328x(03)004492.

Beccali, Marco, Maurizio Cellura, Mario Fontana, Sonia Longo, and Marina Mistretta. 2013. "Energy Retrofit of a Single-Family House : Life Cycle Net Energy Saving and Environmental Benefits." Renewable and Sustainable Energy Reviews 27: 283-93. https://doi.org/10.1016/j.rser.2013.05.040.

Cascio, Ermanno Lo, Zhenjun Ma, Davide Borelli, and Corrado Schenone. 2017. "Residential Building Retrofit through Numerical Simulation: A Case Study." Energy Procedia 111 (September 2016): 91-100.

https://doi.org/10.1016/j.egypro.2017.03.011.

Dall'O’, Giuliano, Luca Sarto, and Angela Panza. 2013. "Infrared Screening of Residential Buildings for Energy Audit Purposes: Results of a Field Test." $\begin{array}{llll}\text { Energies } & 6 & \text { (8): }\end{array}$ https://doi.org/10.3390/en6083859.

Danielski, Itai, and Morgan FrOling. 2015. "Diagnosis of Buildings' Thermal Performance-a Quantitative Method Using Thermography under Non-Steady State Heat Flow." Energy Procedia 83: 320-29. https://doi.org/10.1016/j.egypro.2015.12.186.

Domínguez, Samuel, Juan J. Sendra, Angel L. León, and Paula M. Esquivias. 2012. "Towards Energy Demand Reduction in Social Housing Buildings: Envelope System Optimization Strategies." $\begin{array}{llll}\text { Energies } & 5 & \text { (7): }\end{array}$ https://doi.org/10.3390/en5072263.

“Energy Efficiency 2O18." 2018. International Energy Agency. https://www.iea.org/.

Ferrante, A., G. Mihalakakou, and C. Odolini. 1997. "The Rehabilitation Investigation of a Historical Urban Area." Renewable Energy 10 (4): 577-84. https://doi.org/10.1016/S0960-1481(96)00033-X.

"FLIR E50bx." 20121 (33). https://www.flirdirect.com/product/flir-e50bx-infrared-camera.

Florides, G. A., S. A. Tassou, S. A. Kalogirou, and L. C. Wrobel. 2002. "Measures Used to Lower Building Energy Consumption and Their Cost Effectiveness." Applied Energy 73 (3-4): 299-328. https://doi.org/10.1016/S0306-2619(02)00119-8.

Fokaides, Paris A., and Soteris A. Kalogirou. 2011. "Application of Infrared Thermography for the Determination of the Overall Heat Transfer Coefficient (U-Value) in Building Envelopes." Applied Energy 88 (12): 4358-65. https://doi.org/10.1016/j.apenergy.2011.05.014.

Friess, Wilhelm Alexander, Kambiz Rakhshan, Tamer A. 
Hendawi, and Sahand Tajerzadeh. 2012. "Wall Insulation Measures for Residential Villas in Dubai: A Case Study in Energy Efficiency." Energy and Buildings $\quad 44 \quad$ (1): 26-32. https://doi.org/10.1016/j.enbuild.2011.10.005.

Gagliano, A., F. Nocera, F. Patania, and G. Capizzi. 2013. "A Case Study of Energy Efficiency Retrofit in Social Housing Units.” Energy Procedia 42: 28998. https://doi.org/10.1016/j.egypro.2013.11.029.

Gasparella, Andrea, Giovanni Pernigotto, Francesca Cappelletti, Piercarlo Romagnoni, and Paolo Baggio. 2011. "Analysis and Modelling of Window and Glazing Systems Energy Performance for a Well Insulated Residential Building." Energy \& Buildings 43 (4): $1030-37$. https://doi.org/10.1016/j.enbuild.2010.12.032.

Kalamees, Targo. 2007. "Air Tightness and Air Leakages of New Lightweight Single-Family Detached Houses in Estonia." Building and Environment 42 (6): 2369-77. https://doi.org/10.1016/j.buildenv.2006.06.001.

Kasuda;, T., and P. R. Achenboch. 1965. "The Classified or Limited Status of This Report Applies to Each Page, Unless Otherwise Marked. Separate Page Printouts MUST Be Nrked Accordingly."

Kato, Shinsuke, Katsuichi Kuroki, and Shinji Hagihara. 2007. "Method of In-Situ Measurement of Thermal Insulation Performance of Building Elements Using Infrared Camera." "Proceedings of the Sixth International Conference on Indoor Air Quality, Ventilation \& Energy Conservation in Buildings" 921 (IAQVEC2007).

Klein, S A, W A Beckman, J W Mitchell, J A Duffie, N A Duffie, T L Freeman, J C Mitchell, et al. 2010. TRNSYS 17: A Transient System Simulation Program. Madison: Solar Energy Laboratory, University of Wisconsin.

Kylili, Angeliki, Paris A. Fokaides, Petros Christou, and Soteris A. Kalogirou. 2014. "Infrared Thermography (IRT) Applications for Building Diagnostics: A Review." Applied Energy 134: 53149. https://doi.org/10.1016/j.apenergy.2014.08.005.

Lahlou, Naim. 2011. "Energie, Changement Climatique et Bâtiment En Méditerranée."

Larsen, Knut Einar, Frank Lattke, Stephan Ott, and Stefan Winter. 2011. "Surveying and Digital Workflow in Energy Performance Retrofit Projects Using Prefabricated Elements." Automation in Construction $\quad 20 \quad$ (8): 999-1011. https://doi.org/10.1016/j.autcon.2011.04.001.

Lebied, Meriem, Friedrich Sick, Zakaria Choulli, and Abdelmajid El Bouardi. 2018. "Improving the Passive Building Energy Efficiency through Numerical Simulation-A Case Study for Tetouan
Climate in Northern of Morocco." Case Studies in Thermal Engineering 11 (January): 125-34. https://doi.org/10.1016/j.csite.2018.01.007.

Liu, Y, and D. J. Harris. 2015. "Measurements of Wind Speed and Convective Coefficient on the External Surface of a Low-Rise Building." International Journal of Ambient Energy 36 (5): 225-34. https://doi.org/10.1080/01430750.2013.853204.

Nardi, Iole, Domenica Paoletti, Dario Ambrosini, Tullio De Rubeis, and Stefano Sfarra. 2016. "U -Value Assessment by Infrared Thermography: A Comparison of Different Calculation Methods in a Guarded Hot Box." Energy \& Buildings 122: $211-$ 21. https://doi.org/10.1016/j.enbuild.2016.04.017.

Ohlsson, K. E.A., and T. Olofsson. 2014. "Quantitative Infrared Thermography Imaging of the Density of Heat Flow Rate through a Building Element Surface." Applied Energy 134: 499-505. https://doi.org/10.1016/j.apenergy.2014.08.058.

Rocha, J.H.A, and Y.V Santos, C F Póvoasb. 2018a. "Detection of Precipitation Infiltration in Buildings by Infrared Thermography: A Case Study." Procedia Structural Integrity 11: 99-106. https://doi.org/10.1016/j.prostr.2018.11.014.

Rocha, J.H.A, and Y.V Santos, C F Póvoasb. 2018b. "Evaluation of the Infrared Thermography Technique for Capillarity Moisture Detection in Buildings." Procedia Structural Integrity 11: 10713. https://doi.org/10.1016/j.prostr.2018.11.015.

Romani, Zaid, Abdeslam Draoui, and Francis Allard. 2015. "Metamodeling the Heating and Cooling Energy Needs and Simultaneous Building Envelope Optimization for Low Energy Building Design in Morocco." Energy and Buildings 102: 139-48. https://doi.org/10.1016/j.enbuild.2015.04.014.

Saelens, Dirk, Wout Parys, and Ruben Baetens. 2011. "Energy and Comfort Performance of Thermally Activated Building Systems Including Occupant Behavior." Building and Environment 46 (4): 83548. https://doi.org/10.1016/j.buildenv.2010.10.012.

Tejedor, Blanca, Miquel Casals, Marta Gangolells, and Xavier Roca. 2017. "Quantitative Internal Infrared Thermography for Determining In-Situ Thermal Behaviour of Façades." Energy and Buildings 151: 187-97. https://doi.org/10.1016/j.enbuild.2017.06.040.

"The Thermal Resistance of the Air Layers." n.d. Accessed April 15, 2019. https://www.energiepluslesite.be/index.php?id=16897.

Ultra, Tinytag, Tinytag Ultra, The Tgu-, Popular Applications, and Incubators Features. 2014. "Issue 10.” 